University of Warwick institutional repository: http://go.warwick.ac.uk/wrap This paper is made available online in accordance with publisher policies. Please scroll down to view the document itself. Please refer to the repository record for this item and our policy information available from the repository home page for further information.

To see the final version of this paper please visit the publisher's website. Access to the published version may require a subscription.

Author(s): Jane Lewis and Elaine Welsh

Article Title: Fathering practices in twenty-six intact families and the implications for child contact

Year of publication: 2005

Link to published version: http://dx.doi.org/

10.1017/S1744552305001059

Publisher statement: None 


\title{
Fathering practices in twenty-six intact families and the implications for child contact ${ }^{1}$
}

\author{
Jane Lewis \\ Department of Social Policy, LSE \\ with \\ Elaine Welsh \\ Department of Sociology, University of Warwick
}

\begin{abstract}
The nature of the contribution that fathers make to families is the subject of intense debate by both academics and policymakers. Contact between non-resident fathers and their children has been promoted by government and the courts, but remains difficult to achieve. This paper reports on interview data collected from fathers, mothers and their adolescent children in intact families on the perceptions offathering practices and the factors that influence them. In addition, the nature and extent of fathers' involvement with their children is explored in relation to the problem of 'boundary setting'.

While the traditional, rather distant, breadwinning father has disappeared, there is no evidence from this study of a shift towards the kind of father who takes equal day-to-day responsibility for his children. Rather, the changes in the nature offathers' involvement with their children are more subtle, relying to a large extent on an appreciation of the importance of 'passive care' and of mediation by mothers. We suggest that these findings have important implications for what might be expected by and of fathers when relationships break-up, and for the development of policies to encourage father involvement.
\end{abstract}

Child contact with non-resident fathers has become a highly contentious and increasingly politicised issue in the U.K. as in other English-speaking countries. Academic studies and fathers organisations (particularly Families Need Fathers and Fathers 4 Justice ${ }^{2}$ ) have documented the distress and anger felt by non-resident parents (usually fathers), who feel unable to participate meaningfully in their children's lives (Bradshaw et al., I999; Simpson et al., I995), while contact has been the subject of two government-sponsored consultation exercises (Advisory Board on Family Law, I999, 2002). In 2002, the (then) Lord Chancellor's Department made increasing contact - where it was safe and in the interests of the child to do so - one of its key Public Service Agreement targets. ${ }^{3}$

In England and Wales, under the 1989 Children Act, parents are expected to continue to exercise parental responsibility regardless of their civil status. However, parents who cannot agree on arrangements for contact can apply under the Children Act for a contact order. It was hoped that this piece of legislation, which codified the idea of 'parental responsibility', would encourage both parents to feel concerned and responsible for their children and would help to reduce conflict and litigation (Sclater and Kaganas, 2003). However, while only I0\% of parents use the law to sort out contact arrangements, the volume of disputes has increased and they are taking longer to resolve

I This project is based on research funded by the Joseph Rowntree Foundation.

2 See the websites: www.fnf.org.uk and www.fathers-4-justice.org.

3 This target ended in March 2003, when the LCD's responsibility for children's policy passed to the Department for Education and Skills (and when the LCD became the Department for Constitutional Affairs). 
(Bailey-Harris et al., I998; see also Smart et al, 2003). In addition, a significant minority of nonresident parents had no contact, and among those who do, contact tends to ebb away over time (Bradshaw et al., I999; Simpson et al., 1995).

All this begs the question as to why contact should prove so difficult. As Collier (200I) and Lewis, J. (200I, 200Ia) have both pointed out, government policy in respect of families has increasingly been premised on a new 'family model' in which there is assumed to be gender convergence: of women towards men in regard to paid employment and men towards women in regard to carework and 'active parenting' (see also Smart and Neale, I999; Wallbank, 200I, p. 105). In this model, some form of shared parenting becomes the norm. However, a recent review of the evidence on fathers and fatherhood noted the widespread confusion and disagreement on the contribution that men make to contemporary family life (Lewis, C., 2000). In practice, we know that while there has been a significant increase in men's domestic involvement in intact or 'subsisting' heterosexual families, shared parenting is relatively rare, and men's commitment to the role of primary earner remains strong (Coltrane, I995; Gershuny, 2000; Hatten et al., 2002; Warin et al., I999). We also know that while the evidence that contact is good for children is mixed (Dunn, 2003; Smith et al., 200I), it does seem that it is the nature and quality of the parenting by the contact parent that is important, rather than contact in and of itself (Pryor and Rodgers, 200I).

Much is hoped for from contact, by fathers and also by children (O'Quigley, I999; Hunt, 2003a). But at the very least, we know that it is difficult for non-resident fathers to negotiate becoming 'a different kind of father' (Simpson et al., I995, p. 78; see also Trinder et al., 2002). In an effort to understand more about why this is the case and what may realistically be expected of or by nonresident fathers, we have set out to explore 'fathering practices' (Morgan, I996, I999; Hobson and Morgan, 2002), that is, how and why fathers 'do' fathering, in 26 intact families with adolescent children.

\section{Research on 'fathering'}

As Dowd (2000) has noted, fatherhood is a common life experience for nearly all men and patterns of fathering are increasingly diverse and complex. During the last two decades, research on fathering has been dominated by psycho-social studies of 'father involvement', following Lamb's (I986) influential construction of 'involvement' as engagement, that is, direct interaction with the child; accessibility or availability to the child; and responsibility for the care of the child. Lamb's original construct was intended to be 'content-free', concerning only the quantity of fathers' behavior, time, or responsibility with their children' (Pleck, I997, p. 67, emphasis added), and focused on the provision of care.

It is now widely acknowledged that simple frequency measures say little about the quality of the interaction (Amato and Gibreth, I 999; Cabrera et al., 2000). Indeed, later research has emphasised the importance of the content and quality of involvement in the case of resident and non-resident parenting, and has re-discovered the importance of feelings, for example of closeness and warmth (Amato, 1994; Hetherington and Kelly, 2002). Other arguments as to the need to go beyond measurement based on empirical observation have drawn attention to the extent to which fathers think about their children, while they are at work, for example (Palkovitz, I997). Limited qualitative evidence from the U.K., the U.S., Canada and Australia further complicated the picture by showing that many of the measures of involvement used - for example, closeness - mean different things to men, women and children; that meanings change for any particular actor over time and in relation to changing circumstances (e.g. divorce); and that meanings are negotiated, particularly between mothers and fathers, and mediated, particularly by mothers (e.g. Backett, I982; Hochschild, I990; Coltrane, I996; Lupton and Barclay, I997; and Dienhart, I998).

More difficult still has been the criticism that Lamb's construct of father involvement used what mothers do as the baseline. Thus Hawkins and Dollahite (I997), for example, have argued strongly 
against any notion of a 'deficit model of fathering'. In this view, mothers and fathers make distinctive rather than substitutable contributions (see also Richards, I982). Most recently Lamb (2000) has acknowledged the importance of a range of fathering practices and has urged that more attention should be paid to 'fathers' other responsibilities, beyond their interaction with children: for earning, supporting mothers, and for moral guidance.

The key determinants of 'father involvement' have also provoked debate. Lamb (ig86) identified a hierarchy of factors: motivation, skills and confidence, support (e.g. from mothers) and institutional practices (e.g. provision for parental leave). Thus, an improvement in skills, for example, would be unlikely to lead to an increase in involvement without an increase in motivation. Others have stressed the importance of additional variables, such as identity (e.g. Ihinger-Tallman et al., I995) or of taking a more 'ecological' approach, with more attention to the ways in which fathers balance the different dimensions of their role, for instance earning versus care, and the particular circumstances of their decision (Parke, I996, 2000; Doherty et al., I998). Doherty et al., (I998) have invited consideration of father factors, child factors, mother factors, the co-parental relationship, and contextual factors, which, taken together, comprise a huge number of variables.

There is strong evidence that 'father involvement' is associated with positive outcomes for children, particularly in intact families, but the conceptualisation of both what constitutes involvement' and what gives rise to it are contested. The literature on 'father involvement' has increasingly focused on developing measures of 'positive' involvement, that is, fathering practices likely to promote the development of the child. Our approach has been deliberately normative with the aim of exploring the perceptions of fathering practices and the factors influencing them, because we wish to make a contribution to understanding the difficulties non-resident fathers experience in fathering after relationship break-down.

\section{The study}

The qualitative sample was derived from a quantitative survey on father involvement, carried out in three secondary schools, one inner city, one suburban and one rural, with average OFSTED scores (Welsh, et al., 2004). All the children in each school were asked to complete the survey. In total, 2,2 I 8 children's responses were received, together with I,09I of their parents'. Parents were asked if they were prepared to be interviewed and the sample of 26 intact families interviewed for this study were selected from the 77 intact families who stated their willingness to participate. All parents were married and were the biological parents of the children, whose ages ranged from I I-I6. Table I summarises the characteristics of the sample; particular emphasis was placed on choosing fathers with different educational attainment and different housing tenures. Nevertheless, the sample is somewhat biased towards those with higher educational achievements. Given that mothers and fathers volunteered to be interviewed with their children, we would expect these to be families with minimal conflict, and this was confirmed by the modified parenting inventory (Abidin and Brunner, I995) and child conflict scale scores (Grych, Seid and Fincham, 1992) from the survey data for these families.

Interviews were conducted with mothers, fathers and children separately and focused on the perceptions of each family member about fathering. ${ }^{4}$ Marsiglio et al. (2000) stressed the importance of collecting data from family members other than fathers in future research, because perceptions may vary, and contextualisation is additionally important for a discussion of the influences on fathering practices. In this study, a remarkable degree of consistence in respect of the broad picture of father involvement emerged from all three interviews (see also Kearney et al., 2000).

4 Two interviewers visited each family home. Fathers were interviewed for between one and a half and two hours by one interviewer, and mothers for 45-60 minutes and children for 20-30 minutes by the other interviewer. 


\section{Table I}

Sample Characteristics: adults

\begin{tabular}{|c|c|c|c|c|c|c|c|c|c|c|}
\hline Qualifications & Father & Mother & Employment & Father & Mother & Housing & & Ethnicity & Father & Mother \\
\hline None & 4 & I & Full time & 23 & I4 & Owner-occupier & 20 & White British & 20 & $2 \mathrm{I}$ \\
\hline CSE/O Level/GCSE & II & I4 & Part time & 2 & IO & LA/Council/HA & 5 & White Irish & 2 & I \\
\hline A Level & 3 & 2 & Not working & I & 2 & Other & I & Other White & I & I \\
\hline \multirow[t]{2}{*}{ University } & 8 & 9 & & & & & & Indian & 2 & 2 \\
\hline & & & & & & & & Other Asian & I & I \\
\hline
\end{tabular}

Sample Characteristics: children

\begin{tabular}{lcccccc}
\hline Young Person Sex & & Young Person Age & Male & Female & School Groups & Nos of Families \\
\hline Male & I5 & I I yrs & 0 & I & Rural & I0 \\
Female & I 2 yrs & 2 & I & Suburban & 9 \\
& I 3 yrs & 3 & 3 & Inner-city & 7 \\
& I4 yrs & 6 & 4 & & \\
& I5 yrs & 3 & I & \\
& I6 yrs & I & I & \\
\hline
\end{tabular}




\section{The nature of fathering practices}

From the interviews conducted with fathers we compiled a list of the things fathers mentioned most often, and from this list derived four main dimensions of fathering:

- Activities: doing things with the child.

- Macro- (overarching) responsibility: especially for earning, guiding, leading and steering the child; imposing a moral code and imparting values.

- Micro- (day-to-day) responsibility: e.g. for planning (especially activities and appointments), monitoring the child's friends, and helping with homework.

- Cognitive and emotional involvement: including knowing and understanding the child, talking and listening, thinking about the child, and closeness to the child.

There were four fathers who did not figure in any of these four dimensions and were deemed to have very low involvement. At the other end of the scale, seven fathers figured in more than two dimensions. Both the range and the depth of their fathering practices made them highly involved fathers. Between these poles, it is difficult to come to firm conclusions as to the degree of involvement. Eight fathers figured in only one dimension and seven in two, but the depth of their involvement differed considerably. For example, one father was very involved in sporting activities with his child, but there was little evidence from him or from the mother and child of other forms of involvement, while other fathers provided evidence of more limited involvement on two dimensions. We will refer to fathers as very low or relatively less involved, and as highly or relatively more involved.

\section{Activities}

Given the age of the children interviewed for this study, it might be expected that they would be starting to do rather more with friends and rather less with fathers and other family members. About a third of the sample of fathers reported doing things with their children on a regular basis. These fell into three main groups: those fathers who pressed the child into doing something of interest to the father in the first instance, a similar number of fathers who either took up or accompanied the child in an activity of the child's choosing, and a smaller group where the initiation of activities was more mixed. Not surprisingly, children welcomed the second form of involvement most. Thus a father who organised junior football teams for the whole community insisted that his son, who could no longer play due to injury, act as a referee, even though the child seemed ill at ease in the role and said three times in the course of his interview that he felt rather too young to do this. In another family, the father wanted to go to watch football and the son, whom all three family members acknowledged had no interest in the sport, went along in order to please his dad. While in a third, all three family members reported the father's successive enthusiasms, for rock climbing, biking, wind-surfing, and skiing. As a young boy, the son had been incorporated into each one, such that he felt that his father 'liked to be the centre of attention'. However, the son had developed his own interest in athletics, and the father showed little interest in or knowledge of the son's achievements in this field. This contrasts with the father who took up running in order to join his daughter and the father who sat on the local committees governing each of his son's three sports. There was also a small minority of fathers who seemed to be reluctant to involve their children in their own activities.

\section{Macro-responsibility}

Each father interviewed for this study was asked about the importance of breadwinning, traditionally the most important role of a father, relative to other dimensions of fathering. In all cases, earning was placed either first, last, or was separated from other aspects of fathering, but paradoxically the 
meaning was the same. Fathers (and mothers) were agreed that money made other forms of involvement possible. It was therefore a crucial underpinning, which either had to be put first or last, or could be acknowledged and then put to one side. In two families the mother did not go out to work and in a further three families the mother was the main breadwinner. Most families continued to comply with the typically Western European pattern of a one-and-half earner model family (Lewis, J., 200I), which, while fathers remain the principal earners, has served to dilute the overwhelming importance that was attached to this form of responsibility for fathers in the past.

Two other forms of macro-, or overarching, responsibilities were identified. The first was a large group of fathers (half the sample) who spoke of their role in guiding, leading or steering the child, and indeed sometimes the fortunes of the whole family. Several saw their main responsibility in terms of 'hopefully steering them away from trouble', or more positively providing a 'beacon for guidance'. Warin et al. (1999) reported similar findings: a child in their sample described his father as 'the guiding star' (ibid., p. 35). One father interviewed for this study said that ideally a son would be a kind of 'apprentice under you', who would be guided down the 'right' paths. The expectations of a majority of fathers expressing this sense of responsibility tended to be negative, focusing mainly on keeping the child on the 'straight and narrow' and out of any involvement with drugs and crime. However, given the environment surrounding the inner city and suburban schools and the peer group pressure encountered by a majority of those children (two had recently been mugged), such preoccupations were understandable.

The second form of macro-responsibility, closely linked to this formulation of large responsibilities, was that of laying down a moral code and imparting a set of values. One father said: 'ultimately the bringing up of the children is a responsibility. It falls on values and morals. In fact, I believe ultimately it falls on the father.' He went on to talk of this in relation to trying to ensure the success of his children and the family as a unit. Another father referred to the importance of adhering to a 'moral code in there somewhere, when you feel it is not right', using this to justify his specific objections to his teenage daughter's 'revealing blouse' (filtered to the daughter via the mother, see below p. 9I et seq.). Two British Asian fathers were particularly concerned to influence their children on the matter of family values: 'Now I find that he's returning to me and he is willingly listening. That is the real turning - the value point.' The other British Asian father had told his son many times that he must hold the family dear (which would involve looking after his elderly parents in his turn). A Southern European immigrant father also sought to impart a generational sense of family continuity, without any express injunction to care, to his daughters.

All but six fathers articulated some notion of macro-responsibility in these two senses, often with considerable force. Given this widespread sense of overarching responsibility, it is not surprising that a majority of fathers also identified themselves as the 'backstop', especially in matters to do with discipline, even when their involvement in day-to-day matters, discipline included, was almost universally minimal.

\section{Micro-responsibility}

This is most often associated with sightings of the 'new man', but was conspicuously absent among this group of fathers. Planning, whether for outings or visits to the dentist, together with the day-today running of households and care for the children were by and large left to mothers. The vast majority of fathers would do whatever they were asked to do, but did not initiate responsibility for the task: 'D (wife) ... she's usually the one with the decisions, yeah. I can make decisions for myself, but I ain't very good at coming up with things for other people, you know.' Even in the case of two of the three families in which the mother was the main breadwinner and worked longer hours than the father, fathers did not take equal responsibility for the day-to-day care of children. A partial exception was overseeing homework, which, like disciplinary issues, related directly to the widespread 
assumption of responsibility for guiding and steering. However, even some of the more involved fathers reported being inconsistent in this respect or revealed the extent to which inquiries about homework had become ritualised. In a significant minority of cases, the child had already outstripped his or her father's capacity to help (we return to the issue of fathers' skills and confidence below, p. 90). The area of micro-responsibility in which fathers were most involved was the monitoring of the child's friends (see also Parke, 2000 on this), which again was strongly related to the macro-responsibility that a majority accepted for 'guiding'. The main aim was to ensure that the friends were not a 'bad influence' and would not lead to problematic behaviour.

\section{Cognitive and emotional involvement}

Again, some forms of macro-responsibility, particularly leading, guiding and steering, might reasonably have been expected to translate into some parts of this dimension of fathering, especially perhaps knowing and understanding the child, and talking and listening to the child. However, this proved to be the case for only a minority of fathers. While the vast majority of fathers communicated with their children, there is a need to draw a distinction between 'talk' and 'chat'. For example, a father who worked regular hours and rarely went out in the evenings, would keep up a running commentary on the day's events, or on TV programmes, but reported that he was not able to recognise when his child was upset and that his child approached the mother rather than him for help with any sort of problem. ${ }^{5}$ This kind of chatting, rather than talking as an exchange, particularly about serious issues, characterised a majority of fathers' daily interactions with their children according to both fathers and children.

While the interviews with mothers and children for the most part confirmed the fathers' perceptions of their fathering practices and where their main involvement lay, within each of the four dimensions of fathering there were some disagreements as to the degree to which fathers were involved, and this was particularly true of how much fathers 'listened' to their children. Guiding, leading and steering seemed in many cases to translate into 'talking at'. In the most extreme case, a (highly involved) father reported that he lectured his son, that his son disliked it (which was confirmed by the son and by the mother), but that he considered that 'it's my job to lecture you'. In a further four cases, all highly or relatively more involved fathers, the mothers and the children said that they did not feel that the father listened 'enough'. While one of the fathers said that he made an effort to guide his son and that listening was crucial to that endeavour, the mother said that 'maybe he could listen a bit more', while the son said that his dad was 'really annoying. Sometimes I try to have a serious conversation, but he doesn't really listen ... he doesn't listen properly'. However, those fathers who tended to 'talk at' their children also revealed the extent to which they thought about their children's problems and dilemmas during the day. A significant minority of fathers reported that they recognised the importance of listening to their children, but there was little supporting evidence in the form of talking to their children, or in terms of thinking about the child and understanding what made the children 'tick', even though a majority knew in the abstract what was likely to upset the child, or what the child liked to do. This also meant that many fathers tended to be impatient:

'R's [daughter] a personality where she tends to see offences, where to some degree there's none intended. So she's a bit sensitive. A bit overly sensitive at times, she can see slights were none are intended at times... I mean I normally see things very black and white...I mean, B [wife] understands it more than I do! But maybe I don't show the patience that I might do.'

5 As what follows (pp. 88-89) makes clear, we do not wish to downplay the importance of 'being there', merely to distinguish it from cognitive involvement. 
Evidence as to fathers' emotional involvement with their children was not easy to obtain. Interviewers asked fathers for an instance when they had felt particularly close to their child, but a large number (nine) were unable to provide an example. Nevertheless, a significant minority mentioned the fact either that they were happy that they still got a goodnight kiss, or that they were sad that the child had now reached an age where this, or hand-holding, were no longer deemed appropriate. It is also clear that in the absence of any other form of significant involvement, closeness can be very important (see also Amato, I994; Cabrera et al., 2000). A father who had been absent from his family for a period of almost four years and who did not share any activities with his child, had no large ambitions or sense of overarching responsibility, and who did not know the child very well, told a moving story about comforting his son on the death of a hamster. As he put it, he 'clicked' with the son on this occasion, adding that 'it's not often we click'. On the whole, despite a certain reticence in discussing this form of involvement, it seemed that rather more fathers across the full range of educational qualifications and occupations were emotionally involved with their children than were cognitively involved. ${ }^{6}$

While we were able to distinguish these four forms of fathering, one further dimension was identified by all the fathers and by almost all the children, as well as by many mothers: 'being there'. This can mean everything and nothing, which is why it is not listed as a separate dimension of fathering. Warin et al. (I999) also stressed the importance of fathers 'being there', defining the concept mainly in terms of fathers' availability, and in a recent EOC report, Hatten et al. (2002) identified 'being there' as being available, for example to attend children's sports days. Lupton and Barclay (I997) used the concept in their analysis of an Australian sample of first-time fathers, defining it in terms of fathers' desires to build relationships with their children by doing things together. And Simpson et al. (I995) wrote about divorced fathers as wanting to 'be there', even if only in the abstract, for their children.

While rather different, all these uses of 'being there' share the idea of commitment to fathering. The interviews for this study produced some similar examples, but more striking was the importance attached to 'being there' in the sense of being a passive, caring presence. One highly involved father referred to his most important job as 'emotional being there' and his daughter seemed to echo this when she spoke of a dad 'who is there but not too there, who is around but not too interfering'. At the extreme, in Doherty et al.'s (I998) model of father responsibility, the first responsibility after acknowledging the existence of the child is merely presence. But for the most part, 'being there' meant more than this to the fathers in this study. The father who had left the family home for a period of four years and whose involvement in his family was low, nevertheless spoke enthusiastically of his return and was rated very highly as a dad by his son. One wife of a highly involved father sought to express her appreciation of his 'being there' when she said 'it is important for a dad to be there, validating is the word, validating by being there all the time'. She saw the father's desire to be there as validation of the 'family project' (Morgan, I996). A large number of mothers and children spoke above all of the importance of fathers 'being there' for security and stability. Passive care has long been argued by feminists to be under-valued in respect of mothers and of carers for elderly people, and it seems from our evidence that this may also be the case in respect of fathers.

In the case of three fathers in this sample 'being there' in the sense of mere presence was the sum total of their involvement, but in all three cases they were also 'jokey', 'fun' dads. 'Being there' and being a jokey, fun dad when present is something that fathers can do regardless of working hours (ten fathers in the sample worked more than 48 hours per week). We were able to classify no fewer

6 It should be noted that there were a number of opportunities, direct and indirect, in the interview for fathers to reveal cognitive involvement. 
than 18 of the fathers as 'jokey' dads. Several of these fathers spoke of their belief that they should try to 'make the house happy'. One said that he was 'best at' making them all laugh 'I am worse than the kids... They all sit there and laugh at me half of the time... I just sit there and act the fool and they all laugh at me'. Frosh et al. (2002) found that fun dads were very important to children, something that was confirmed by the children we interviewed. In three of the cases where fathers had a strong sense of macro-responsibility but were not fun dads, the children spoke rather negatively about them, and on balance, it was possible for a father's sense of fun to mitigate his lack of other forms of involvement (see also Hatten et al., 2002). The father who had little understanding of (or patience with) his daughter's dramas, who worked long hours, and who was not very involved, was nevertheless a fun dad, which was much appreciated by his daughter. However, it is also possible for fun dads not to take the business of talking to their children sufficiently seriously as the quotation above (p. 87) from the boy who was annoyed that his father did not listen to him showed. Being there and being a jokey dad may link more readily to 'chat' than to talking and listening, and to emotional rather than cognitive involvement, although Frosh et al. (2002) also found that children often see 'fun' dads as immature and suggested that this same immaturity makes it difficult for the father to help with emotional problems.

Thus the most common pattern of involvement for the fathers in this sample was that of macroresponsibility (in the case of 22 fathers) or 'being there' as a jokey dad (in I 8 cases); I 2 fathers combined all of these. This makes it possible to interpret the nature of fathering practices in this sample as rather traditional. Macro-responsibility is more 'caring about' than 'caring for' (Neale and Smart, I999; Finch and Groves, I983; Tronto, I993). So-called 'new fathers', actively involved in co-parenting, would be expected to take more micro-responsibility, involving themselves in the day-to-day tasks of 'caring for', and to be more cognitively and emotionally involved with their children.

Traditional fathers in male breadwinner/female carer families were expected above all to take responsibility for providing for their families, but the fathers in this sample, while acknowledging earning as being of fundamental importance, nevertheless tended to separate it from the other dimensions of fathering in a manner not dissimilar to the modern American writers on the concept of father involvement (Pleck and Stueve, 200I). Only one father, an academic working long hours, tended to wrap up his work into his roles of husband and father. In the words of his wife: 'I think he would see being a husband bound up with being a worker - as a provider. And that also as a parent, he does provide for his offspring through being a worker.' Only this father could be described as consciously 'distant' from his children in the traditional manner of the paterfamilias. Almost all the rest expressed considerable interest in and/or concern about their children, even if they were 'very low' involved fathers. A small majority engaged in more than one dimension of fathering, but the depth of their involvement was still often slight compared to that of mothers. Thus, on balance, while their involvement did not follow the traditional pattern of breadwinning and little else, nor was it distinctively 'new'.

Indeed, fathers tended to be more 'family-centred' than 'child-centred' (that is responsive to the child's needs and wishes), while mothers tended to be the opposite. The father who insisted that his son take up refereeing did not seem to appreciate that his son had little taste for this activity, and the common complaint from children and mothers that fathers did not listen also suggested engagement on the father's terms. But children often seemed to recognise and appreciate the different nature of fathers' involvement, the son of the 'lecturing' father rated him very highly as a dad. Fathers themselves often insisted that they were, or wanted to be, 'family men'. The father who had left the family home for four years said: 'I don't ever say I'm going home to me house, I'm always going home to Y [wife] and the kids...' ' This commitment to home and family was valued by mothers and children. The desire of an army father (who had missed most of his children's growing up) to 'be there' was appreciated by his daughter, who compared her lot favourably to that of a friend who lived in a lone parent family. 


\section{Influences on fathering practices}

Explaining the nature of fathering practices is complex; there are many reasons why fathers may be more or less involved with their children. Doherty's (I998) model suggests that father factors, such as skills and confidence; child factors, such as the child's temperament; and environmental factors, such as working hours are important 'determinants'. It was not possible to elicit systematic evidence as to the influences on fathering or, more importantly still, their relationship one to the other, from these interviews. Qualitative evidence in respect of the child's disposition, for example, would have to be collected over time. While the quantitative part of the project provided a measure of the child's temperament, we do not know whether a 'difficult' child was a crucial factor in making it difficult for the father to get involved, or whether difficult behaviour and disposition were more a result of the father's long-standing inability to be involved. One mother commented that she had changed her mind about her son's disposition in the interval between filling in the survey and the interview. In that space of six months her son had become a much more 'difficult' teenager.

Three influences on fathering practices and the extent to which fathers get involved with their children were identified as being particularly important from the interviews: working hours, fathers' own skills and confidence, and the mother/father relationship. Interview data were most plentiful in respect of the last of these, and permit us to draw some conclusions about the way in which the parental relationship was crucial to fathering practices.

Fathers' working hours, have often been identified as a major barrier to active fathering. However, long hours, usual in the case of ten fathers, were not identified in and of themselves as an impediment to involvement by the majority of those fathers, or by other family members, although in several of these families the children said that they wished they had more time with their fathers. However, the desire for more time with dad was also expressed by children whose fathers worked regular hours but who were, for example, regularly involved in their own sporting and/or community activities. In a family where both the mother and father worked long hours, no one in the family found this work pattern to be problematic, which tends to support Burgess's (I997) point that parents who put time into work are not necessarily 'bad' parents. One 'highly involved' father worked a 72-hour week in the restaurant trade, but was home in the mornings before the children went to school and when they came home from school, making it possible for him to talk to them, which he did at considerable length. He also devoted his day off entirely to his children and extended family. However, in the families where the fathers acknowledged the stress arising from their long hours at work, both the mothers and the children commented on the father's tiredness. This suggests that long hours are likely to become problematic for children when they are problematic for adults.

A significant minority (seven) of fathers lacked skills and confidence. All these fathers stated a strong belief in establishing some kind of behavioural and moral boundaries for their children; one had expressed his hope that he would be able to 'lead' his son and that the son would be somewhat like 'an apprentice' (see above, p. 86). However, his wife reported that the father could not communicate with or about his son, while the son said that he did not take his father seriously; he felt that 'mums are more serious and dads are fun and like sports'. Those fathers with low educational qualifications were already unable to help their children with their homework. ${ }^{7}$ One acknowledged this (and the feelings of inadequacy it engendered): 'I'm always willing to try. But I'm not always capable of knowing.'

7 Harris and Marmer (I996) found (for a representative U.S. sample) that in non-poor families both mothers and fathers encouraged the educational achievements of adolescent children, but in poor families this fell to mothers. 
The interviews for this study contained most information about and most reference to the parental relationship. McBride and Rane (I998) have suggested that the 'parenting alliance' (Abidin and Brunner, $1995^{\circ}$ ) may serve as an important predictor of father involvement. Certainly, the literature is agreed that 'context', particularly in the form of the mother/father relationship, is a more important determinant of fathering than it is of mothering (e.g. Gerson, I993; Eggebeen and Knoester, 200I). Stueve and Pleck's (200I) analysis of parenting narratives found that fathers were more likely to construct their parental identity relating to caregiving, promoting development, arranging and planning (micro-responsibility), as well as their relationship with the child (cognitive and emotional involvement), as co-parental. The interviews for this study also show that close cooperation between parents is an important influence in securing the involvement of fathers with their children.

Fathers tended to work through the mothers to 'implement' the framework of values they espoused, or to 'steer' the child in a particular direction, and also relied on mothers to interpret the child's mood or behaviour. In this sample of intact families the commitment to (if not the practice of) co-operative parenting was universally strong, even in the four cases where father involvement was very low (in one of these families, mother involvement was also low, while in the remaining three there was a large measure of agreement that the mother would 'do' the parenting). A majority of mothers enabled fathers to be involved, mainly by talking to fathers about the child. A majority of fathers spent more time talking to mothers about their children than to their children directly, and sometimes were even advised/told when to talk to their children about a particular issue: "Yes, if " $\mathrm{X}$ " [wife] thinks that I should speak to her [daughter] - she will ask me or will say she [daughter] has asked me not to tell you something or other.' The only family in which the marital relationship was difficult (according to the father) nevertheless operated what both the parents and the child considered to be a successful parenting strategy. In this case the father said that if he felt there was a problem (the example was his daughter's 'revealing' blouse), he would talk to his wife and she would then talk to the daughter.

As Furstenberg (I988) has commented, women 'orchestrate' fathers' involvement (see also Backett, I982; Marsiglio, I995; Simpson et al., 1995). Some of the literature on father involvement (e.g. Lamb et al., I987), together with the recent U.K. policy documents on 'contact' (LCD, 200I), has suggested that mothers may 'gatekeep' and effectively stop fathers getting more directly involved with the children, but there was no evidence of gatekeeping in this sample. Fathers were often involved at one step removed, via mothers. But in this sample this was by agreement with the mothers and had very little by way of significant adverse affects on the appreciation of their role by mothers and children.

The I 2 fathers who had very low or relatively less involvement had not become engaged with their children via the mothers, and this, together with the absence of any real effort on the part of the father to engage independently, raised problems for mothers and children. For example, the academic father, who elided his role of breadwinner with those of husband and father, seemed to see his reluctance to initiate any interaction with his daughter as a virtue: 'I hope that I am relatively undemanding ... I think I really have to wait to be asked.' But the mother would have liked him to be more involved, although she had long accepted that he would 'fill up his time with work'. She reported that his lack of involvement meant that 'things tend to surprise him more because he is not aware of what is going on so much ...' and he would then lose his temper, which she found difficult. The daughter was more robust in her criticism. She wanted a dad who was more 'friendly and jokey', like her friends' dads. As it was, she felt that she did not want to spend time with him:

8 Abidin and Brunner (I995) define co-parenting in terms of investing in children; valuing the partner's involvement; respecting the partner's parenting judgement; a desire to communicate. 
'I suppose I should say that I want to spend more time with him, because I don't spend much time with him. I hardly talk to him. I don't know, I don't think I have that much in common with him ... I would like to better friends with him, but I don't really want to be ...'

\section{Fathers' involvement in setting boundaries}

The exploration of a particular issue provides a lens for the examination of the nature of fathering practices, the influences on them and the way in which fathers become involved. In all but nine families, the issue of discipline and setting boundaries for the child was considered important and occupied a considerable amount of space in the interview transcripts, as might be expected in families with teenage children. In the inner city school this issue was complicated by the problem of securing the child's safety, children in two of the seven families interviewed from this school had been mugged. In respect of the nine families for whom boundaries were not an issue, two were members of religious groups, which provided a strict external moral code, and the parents also made sure that their children mixed socially with other children of the same belief. In the remaining families, the children were mainly girls at the younger end of the age range in the sample, or boys who maintained very strict regimes due to their involvement in sport.

The majority of fathers discussed the issue of boundaries with mothers and usually saw themselves as acting as a 'backstop' on disciplinary matters as part of their macro-responsibility for guiding and value setting. Agreeing boundaries in these families often required considerable discussion. Interviewers were given glimpses of the nature of the debate at several points in the adult interviews. One father returned three times to the problem of monitoring the videos his son watched. He had taken the responsibility of telephoning the father of his son's friend to discuss the problem, but commented 'you can't police all the time', and 'they're pushing the boundaries all the time'. The mother also commented at length on the discussions that lay behind the way in which they dealt with the video problem and the problems of 'getting the balance'. A majority of these I 7 fathers parented authoritatively in the sense of bringing a view to the discussions with their partners ${ }^{9}$, albeit that most remained at one step removed on a day-to-day basis. The daughter of a father who worked long hours and was often away from home said that 'he has got quite big morals ... and he is good at making you see sense'. Her father, she said, would give the 'long story' on what to do. Her mother had to take responsibility on a daily basis for monitoring the children's behaviour and she felt that her husband should be 'more decisive and more consistent' in respect of discipline. This was a common complaint from mothers: that they agreed 'boundaries' with fathers, but then fathers all too often gave in. Another mother, in a family where the father adhered to a very strict code of family values and respect for elders, described her husband as 'quite happy to sit on the edge and let life go on'. Having agreed boundaries for the son with the father, she took responsibility for making sure that he kept within them, and in her case was happy to do so.

The input of highly involved fathers was subtly different usually because of their greater knowledge and understanding of the child, or because they put considerable effort into thinking about the best course of action at that particular moment in the child's development. In one of the inner city school families, the son (who had been mugged and who rated his dad as a 'ten out of ten top dad') nevertheless wanted to spend more time with his friends:

'I would just prefer to spend less time with my family, not because I don't like them. I love them, but I just spend too much time with them. I just want to be able to hang out with my friends and do something spontaneous or something, but of course it wouldn't be safe and stuff.'

9 Baumrind (I968) identified the importance of authoritative as opposed to authoritarian parental control. More recently Marisglio et al. (2000, p. I I82) have defined it as having characteristics that overlap substantially with indices of 'father involvement'. 
The son reported that his dad got on with his friends, but could not understand how they could have lost three footballs, or why they ate so much when they came round: 'dad seems to think my friends take advantage of me while I am just being nice and giving hospitality.' In their interviews, the mother and father both insisted on the importance of maintaining 'a united front'. This father had expressed his wish to be a 'beacon for guidance' (see above, p. 86) for his children, felt that he was a 'strong figure' in the family and admitted his lack of patience. But he discussed at length the extent to which he would 'agree' disciplinary issues with his wife, and also the extent to which he was involved in thinking about his son's development:

'I was only reflecting on this to myself this morning... on some of the signs that he is changing...thinking about his current situation... how he's evolved and sort of starting to strike out, because after the mugging you see he wouldn't go anywhere ... I want him to be able to walk out of the door with confidence ... what was the question again?'

This father's constant reflection on his son's needs made him more child-oriented than the vast majority of fathers in the sample and a particularly well-informed participant in the discussions with his wife about how to handle the problem of boundary setting.

In a significant minority of families (five), where the fathers accepted macro-responsibility for guiding and setting values, and where there were problems of boundary setting, they nevertheless did not play any major part in addressing the issue. These men all lacked skills and/or confidence as fathers. Two also said that they had been 'young tearaways' themselves, which may have made them uneasy in setting boundaries in their turn. ${ }^{\text {IO }}$ None of these fathers simply abnegated responsibility for setting boundaries. Rather, all sought to rework their ideas about their macro-responsibilities in such a way as to be compatible with their inability to address the issue. All five reported that their teenage children were now more independent and did not therefore need them:

'They're so independent, they want to do their own thing, they don't need me.'

'I want him out there doing things for himself.'

'He seems quite happy on his own, he's got his friends.'

A father who worked long hours commented that a year ago he might have said that his working hours were an impediment to involvement, but now his son had his own friends and was more independent, so he was not needed. Thus the child seeking greater independence was constructed as both a natural and a desirable development, and was used to justify the fathers' lack of involvement in addressing one of the major parenting issues facing these families.

In the view of the very low involved academic father, his daughter's 'independent nature' meant that she did not invite his involvement, so, unless she went seriously 'off the rails', he could justify standing back. The daughter felt that she had nothing in common with her father (see above p. 87) and went on to describe how their inability to communicate on any level resulted in a series of arguments: 'I would like to be better friends with him, but I don't really want to be. It is like I like having my independence and stuff, but I would have liked to - we have really petty arguments.' In the one family where both the father and mother had very low involvement and where the father did not assume any macro-responsibility for his children, it was the mother who used the idea of her daughter's growing independence to justify standing back from the boundary-setting issue. She knew that the I4-year-old daughter was spending her evenings in her I 8-year-old boyfriend's home, but said only that this was 'quite nice, it gets her out'. The father talked at length about his inability to

Io While the American studies of father involvement attach great importance to the influence of a father's own father on him, mention of the father's own behaviour in adolescence and young adulthood is rare. 
cope with his daughter's tantrums: 'C [daughter] will shout and scream and come back an hour later and ask for money [which he gives]... you know for a peaceful life. I know I shouldn't'. In this (extreme) case, the father made no claim to lead, guide or act as a backstop. The mother did not blame the father in any way and had also effectively given up trying to control the child. Very few fathers relied on any support in parenting beyond mothers, although in the case of this family, the father drew comfort from the fact that a friend was having similar difficulties with his daughter.

The issue of boundary setting shows the difference between taking macro- and micro-responsibility, and further illustrates the importance of co-operative parenting and 'father factors' (in the form of skills and confidence) to the process by which fathers engage with their children. Often, fathers who lacked skills and/or confidence also failed to address the issue of boundary setting. Children were quick to recognise when their fathers could not cope and to judge them accordingly; mothers often wished that fathers would 'do more', but at the same time usually felt that they were doing their best.

\section{Conclusion}

This research is based on interviews with a sample of intact, functioning families, exhibiting no major signs of strain; only one of the children in the sample seemed to have serious behaviour problems. Furthermore, many of the children interviewed were able to provide a mature assessment of their fathers' strengths and weaknesses, thus a dad might be described as 'very annoying' in one or two respects, but nevertheless be rated highly overall. The nature of the fathering practices nevertheless raises important issues in the context of family change and the conviction on the part of policymakers that contact with non-resident fathers is to be encouraged and, by implication, should be easily achievable (LCD, 200I, 2002). The vast majority of fathers did not take day-to-day responsibility for their children's welfare.

The fathers were all to a greater or lesser extent committed to and interested in their children, the main forms of involvement being a commitment to 'be there', often as a jokey, fun dad, alongside a conscious acceptance of macro-responsibilities for guiding, leading and establishing value frameworks. Indeed, fathers' involvement in this last respect was much more likely to be valued by children if the father was deemed to be 'fun' or to be trying to make other family members happy. Many of the fathers who took their macro-responsibility seriously, but who were not jokey dads were somewhat resented by their children, while many of the 'fun' dads who took no macro-responsibility tended to be dismissed by their teenage children. For fathering practices to be perceived favourably by mothers and children, fathers needed to do a bit more than just earn, or just 'be there', or just look after the 'big picture'. While a small majority of fathers were moderately or highly involved, in almost all cases mothers took the bulk of the responsibility for the daily 'running' of the family and also for talking to and dealing with children's problems, discipline included. Fathers tended to report feeling emotionally involved with their children, although more than a third were unable to provide any examples of when they had felt especially close to them. These fathers were not traditional, distant breadwinners, but the evidence from this study supports the view that their involvement remains significantly different from that of mothers (and that it is usually appreciated as such).

The process by which fathers engaged with their children about matters of importance to them had much to do with mothers and co-operative parenting. All the mothers and fathers in this sample shared ideas about the importance of co-operative parenting, even in the one case where the child was beyond the effective control of either parent. Mothers often served as the conduit for fathers to 'reach' their children about issues such as boundary setting. In the course of their work on separation and divorce, Furstenberg and Cherlin (I99I) noted that for many men mothers and children come as a 'package deal'; fathering is widely accepted as depending more on context than mothering. 
This study helps us to understand why this may be the case and why also so many fathers therefore find it difficult to maintain contact with their children after the marriage ends. If a father's main contribution is the provision of passive care by 'being there', then clearly this cannot be sustained after separation. The non-resident parent who expresses the hope of 'being there' for his children nevertheless is in danger of being forgotten. Policymakers often express most concern about the absence of 'guidance' if a father is non-resident (e.g. House of Lords, Debates, 200I, v. 62 I, c. 327). But if a father persists in trying to take macro-responsibility for his children when he is non-resident, he is likely to cause resentment on the part of the mother, who may then indeed turn into a 'gatekeeper' (Ihinger Tallman et al., I 993). Furthermore, non-resident fathers are likely to be plunged into contact that requires taking micro-responsibility, if only on weekends, and cognitive involvement, which again they may well not have experienced. Even intact, two-parent families, are likely to experience problems in sustaining the prevalent model of fathering revealed by this study, especially if mothers as well as fathers work full-time, although one family interviewed had been successful in this respect.

The parenting relationship emerges from this study as key to understanding the way in which fathers engage with children. But as the consideration of the issue of boundary setting showed, 'father factors' are also important. A significant number of fathers lacked skills and confidence in this respect. Given that the kind of gendered division of labour in respect of parenting revealed in this study cannot survive relationship breakdown, the absence of such skills and confidence is likely to become an even greater problem for non-resident fathers seeking to become a different kind of father (see also Smart et al., 2003). However, only one father in this study acknowledged skills and confidence to be a problem and none showed any personal enthusiasm for help in the form of parenting classes. Only two already highly involved fathers thought that such classes might be helpful to themselves, rather than to other fathers. A structural determinant of involvement in the form of long working hours appeared to be significant only if the father and/or the mother found them to be problematic, which suggests that long hours as a barrier to involvement work through either co-operative parenting or 'father factors'. Only if a parent regarded the father's working hours as stressful and as an impediment to involvement did the child also comment negatively on them. Again there was no support from fathers for policy intervention on this issue, but some mothers and children wanted fathers to be able to choose to work fewer hours.

The erosion of the male breadwinner model family has not brought into being 'new fathers' committed to the equal sharing of unpaid care work (any more than it has resulted in fully individualised, full-time earner couples). Indeed, it is hard to judge exactly how far fathers are doing new and different things. It is, for example, difficult to date the emergence of the 'fun' dad ${ }^{\mathrm{II}}$, while the assumption of macro-responsibilities is as firmly associated with the Victorian paterfamilias as with these fathers. But the process of involvement (via the mother/father relationship) revealed in these interviews is much more recent. A majority of fathers discussed their children and their problems at length with mothers and thus negotiated an involvement in issues that went beyond 'general chat'. ${ }^{\mathrm{I} 2}$ Just as it is difficult to know whether the predominant Western European one-and-a-half earner model family represents a transitional form or more lasting compromise, so it is difficult to know how stable the nature of fathering practices reported for this group of intact families is likely to be. The nature and extent of father involvement in intact families is increasing, albeit slowly (Gershuny, 2000; Cabrera et. al, 2000), so encouragement of this trend in the hope that it

I I LaRossa (I 997) dates it to the inter-war period for the U.S. (and also concludes that the growing expectation that dads should be 'pals' served to 'trivialise' fatherhood). Mintz (I998) suggests that men's roles in families have always been diverse.

I 2 Recent research on the family has stressed the importance of negotiation: Finch and Mason, I993; Lewis, 200I; Smart and Neale, I999a; Smart, Neale and Wade, 200I; Weeks et al., r999. 
will take root and survive family disruption would seem to be a promising focus for policy development. This puts the focus firmly on family policies designed to 'reconcile' work and family responsibilities for men as well as for women (Reeves, 2002; O'Brien and Shelmilt, 2002), something that other Northern European countries have sought to encourage by, for example, the provision of 'daddy leaves' when children are young, as in Scandinavia, or the promotion of a 'combination scenario' of part-time work and part-time care for men and women, as in The Netherlands. If there is continued movement towards full-time earner couples, and if more non-resident fathers seek contact with their children, then a more equal pattern of involvement for mothers and fathers and a firmer shift towards 'new' fathering practices would seem to be necessary.

\section{References}

ABIDIN, R.R. and BRUNNER, J.F. (I995) ‘Development of a Parenting Alliance Inventory', Journal of Clinical Psychology 24: 3I-40.

Advisory Board on Family Law: Children Act Sub-Committee (I999) Report to the Lord Chancellor on the Question of Parental Contact in Cases where there is Domestic Violence. London: LCD.

Advisory Board on Family Law: Children Act Sub-Committee (2002) Marking Contact Work. A Report to the Lord Chancellor on the Facilitation of Arrangements for Contact between Children and their Non-Resident Parents and the Enforcement of Court Orders for Contact. London: LCD.

Aмato, P.R. (I 994) 'Father-Child Relations, Mother-Child Relations, and Offspring Psychological Wellbeing in Early Adulthood', Journal of Marriage and the Family 56: I03 I-I042.

амато, P.R. and GiвREтH, J.G. (I999) 'Non-Resident Fathers and Children's Well-Being: A Meta-Analysis', Journal of Marriage and the Family 6r: 557-573.

BaCketT, K.C. (1982) Mothers and Fathers. A Study of the Development and Negotiation of Parental Behaviour. London: Macmillan.

Bailey-harris, R., DAvis, G., BARron, J. and PeArCE, J. (I998) Monitoring Private law Applications under the Children Act: A Research Report to the Nuffield Foundation. Bristol: University of Bristol.

Baumrind, D. (I968) 'Authoritarian versus Authoritative Parental Control'. Adolescence 3: 255-72.

bradshaw, J., stimson, C., williams, J. and skinner, C. (1999) Absent Fathers. London: Routledge. BURGESS, A. (I997) Fatherhood Reclaimed. The Making of the Modern Father. London: Vermilion. CABrera, N.J., TAMis-Lemonda, C.S, BRAdley, R.H., hofferth, S. and lamb, M.E. (2000) 'Fatherhood in the

Twenty-First Century', Child Development 7 I: I27-136.

Collier, R. (200I) 'A Hard Time to be a Father?: Reassessing the Relationship between Law, Policy and

Family (Practices)', Journal of Law and Society 28: 520-545. coltrane, S. (I996) Family Man. Oxford: Oxford University Press.

Day SClater, S. and Kaganas, F. 'Contact: Mothers, Welfare and Rights', in A. Bainham, B. Lindley,

M. Richards and L. Trinder (eds.) Children and their Families: Contact, Rights and Welfare. Oxford:

Hart Publishing.

DienharT, A. (1998) Reshaping Fatherhood. The Social Construction of Shared Parenting. London: Sage.

DOHERTY, W.J., KOUNESKi, E.F., ERICKSON, M.F. (I998) 'Responsible Fathering: an Overview and Conceptual

Framework', Journal of Marriage and Family 60: 277-292. Dowd, N.E. (2000) Redefining Fatherhood. New York: New York University Press.

Dunn, J. (2003) 'Contact and Children's Perspectives on Parental Relationships', in A. Bainham,

B. Lindley, M. Richards and L. Trinder (eds.) Children and their Families: Contact, Rights and Welfare. Oxford: Hart Publishing.

EgGebeen, D.J. and Knoester, C. (200I) 'Does Fatherhood Matter for Men?', Journal of Marriage and Family 63: 38I-393.

FinCH, J. and GRoves, D. (I983) Labour and Love. Women, Work and Caring. London: Routledge and Kegan Paul. 
Finch, J. and MASON, J. (I993) Negotiating Family Responsibilites. London: Tavistock/Routledge.

frosh, S., phoenix, A. and puttman, R. Young Masculinities. Understanding Boys in Contemporary Society.

London: Palgrave.

furstenberg, F. (I988) 'Good Dads - Bad Dads: Two faces of Fatherhood', in A. J. Cherlin (ed.) The

Changing American Family and Public Policy. Washington: The Urban Institute Press.

furstenberg, G. and cherlin, A. (I99I) Divided Families. What Happens to Children when Parents Part.

Cambridge Mass.: Harvard University Press.

Gershuny, J. (200I) Changing Times. Oxford: Oxford University Press.

GERSON, K. (I993) No Man's Land. Men's Changing Commitments to Family and Work. New York: Basic

Books.

GRYCH, J.H., SEID, M. and finchman, F.D. (I992) 'Asessing Marital Conflict from the Child's Perspective'.

Child Development 63: 558-572.

HARRIS, K. and MARMER, J. (I996) 'Poverty, Paternal Involvement and Adolescent Well-Being'. Journal of

Family Issues I 7: 6I 4-640.

Hatten, W., vinter, L. and williams, R. (2002) Dads on Dads: Needs and Expectations at Home and at Work.

London: Equal Opportunities Commission.

Hawkins, A.J. and Dollahite, D.C. (I997) Generative Fathering. London: Sage.

hetherington, E. Mavis and kelly, J. (2002) for Better or for Worse: Divorce Reconsidered. New York:

W.W. Norton and Co.

Hochschild, A. (I990) The Second Shift. London: Piatkus, Ist edn, I989.

hunt, J. (2003) Child Contact with Non-Resident Parents. Family Policy Briefing 3. Oxford: Oxford

University, Department of Social Policy and Social Work.

ininger-Tallman, M., Pasley, K. and Buehler, C. (I993) 'Developing a Middle-Range Theory of Father

Involvement Post-Divorce', Journal of Family Issues I4: 550-57 I.

ininger-TAllman, M., PASLey, K. and buehleR C. (I995) 'Developing a Middle Range Theory of Father

Involvement Postdivorce', in W. Marsiglio (ed.) Fatherhood: Contemporary Theory, Research and

Social Policy. London: Sage.

Kearney, J., mansson, S.-A., plantin, L., pringle, K. and Quaid, S. (2000) Fatherhood and Masculinities.

Sunderland: Centre for Social Research and Practice, University of Sunderland.

LAmb, M.E. (I986) 'The Changing Role of Fathers', in M.E. Lamb (ed.) The Father's Role. Applied

Perspectives. New York: John Wiley.

LAMB, M.E. (I997) 'Father and Child Development: An introductory Overview and Guide', in

M. E. Lamb (ed.) The Role of the Father in Child Development New York: John Wiley, 3rd edn.

LAmb, M.E., PLeCK, J.H. and LEvine, J.A. (I987) 'The Effects of increased Paternal Involvement on Fathers

and Mothers', in C. Lewis and M. O’Brien (eds.) Reassessing Fatherhood. New Observations on Fathers

and the Modern Family. London: Sage.

LAROSSA, R. (I997) The Modernization of Fatherhood. A Social and Political History. Chicago: University of Chicago Press.

LCD (200I) Making Contact Work. A Consultation Paper from the Children Act Sub-Committee of the

Lord Chancellor's Advisory Board on Family Law on the facilitation and enforcement of contact.

London: LCD.

LCD (2002) Making Contact Work. A Report to the Lord Chancellor on the facilitation of arrangements

for contact between children and their non-residential parents and the enforcement of court

orders for contact. London: LCD.

LEwIs, C. (2000) A Man's Place in the Home: Fathers and Families in the U.K. York: Joseph Rowntree

Foundation.

LEWIS, J. (200I) The End of Marriage? Individualism and Intimate Relations. Aldershot: Edward Elgar.

LEwIS, J. (200Ia) 'The Decline of the Male Breadwinner Model Family', Social Politics 8: 152-I69.

Lupton, D. and BARCLAy, L. (I997) Constructing Fatherhood. London: Sage. 
MCBRIDE, B.A. and RANE, T.R. (I998) 'Parenting Alliance as a Predictor of Father Involvement: an

Exploratory Study', Family Relations 47: 229-236.

Marsiglio, W. (ed.) (I995) Fatherhood: Contemporary Theory, Research and Social Policy. London: Sage.

MARSiglio, W., Amato, P., DAY, R.D., LAmb, M.E. (2000) 'Scholarship on Fatherhood in the I99os and

Beyond'. Journal of Marriage and the Family 62: I I73-II9I.

minTz, S. (I998) 'From Patriarchy to Androgyny and Other Myths: Placing Men's Family Roles in

Historical Perspective', in A. Booth and A. C. Crouter (eds.) Men in Families: when to they get involved and what difference does it make? Mahwah, N.J.: Lawrence Erlbaum Associates.

morgan, D.H. J. (I996) Family Connections. Cambridge: Polity Press.

morgan, D.H. J. and hobson, B. (2002) 'Introduction: Making Men into Fathers', in B. Hobson (ed.)

Making Men into Fathers: Men, Masculinities and the Social Politics of Fatherhood. Cambridge:

Cambridge University Press.

NEAle, B. and SMART, C. (I999) 'In Whose Best Interests? Theorising Family Life Following Parental

Separation or Divorce', in S. Day Sclater and C. Piper (eds.) Undercurrents of Divorce. Aldershot:

Dartmouth.

o'BRIEN, M. and SHEMILT, I. (2002) Working Fathers. Earning and Caring. London: EOC.

o'Quigley, A. (I999) Listening to Children's Views and Representing their Best Interest: A Summary of Current

Research. York: Joseph Rowntree Foundation.

PARKE, R. (I996) Fatherhood. Cambridge, MA: Harvard University Press.

PARKE, R. (2000) 'Father Involvement: A Development Psychological Perspective', Marriage and Family

Review 29(2/3): 43-58

PALKovitz, R. (I997) 'Reconstructing “Involvement”. Expanding Conceptualizations of Men’s Caring in

Contemporary Families', in A. HAwkins et al. Generative Fathering, pp. 200-2 I6.

PLECK, J.H. (I997) 'Paternal Involvement: Levels, Sources, and Consequences', in LAMB (ed.) The Role of

the Father in Child Development. New York: John Wiley and Sons, 3rd edn.

Pleck, J.H. and stueve, J.L. (200I) 'Time and Paternal Involvement', in K. DALy (ed.) Minding the Time in

Family Experience: Emerging Perspectives and Issues. Contemporary Perspectives on Family

Research vol. 3. JAI Press.

PRYOR, J. and RODGERS, B. (200I) Children in Changing Families: Life after Parental Separation. Oxford:

Blackwell.

REEVES, R. (2002) Dad's Army. The Case for Father-Friendly Workplaces. London: The Work Foundation. RICHARDS, M.P. M. (I982) 'How should we approach the study of fathers?', in L. McKee and M. O’Brien

(eds.) The Father Figure. London: Tavistock.

SIMPSON, B., MCCARTHY, P. and WALKER, J. (I995) Being There: Fathers after Divorce. Newcastle, Relate Centre for Family Studies.

SMART, C. and NEALE, B. (I999) ' “I Hadn’t Really thought About It”: New Identities/New Fatherhoods',

in J. Seymour and P. Bagguley (eds.) Relating Intimacies: Power and Resistance. Houndmills:

Macmillan.

Smart, C. and neale, B. (I999) Family Fragments. Cambridge: Polity.

Smart, C., neale, B. and WAde, A. (200I) The Changing Experience of Childhood. Families and Divorce.

Cambridge: Polity.

SMART, C., MAY, V., WADE, A. and furniss, C. (2003) Residence and Contact Disputes in Court. vol. I. London:

LCD, Research Series 6/03.

Smith, M., robertson, J., Dixon, J., Quigley, M. and whitehead, Z. (200I) A Study of Stepchildren and Stepparenting. London: Thomas Coram Research Unit.

Stueve, J.L. and PlecK, J.H. (200I) ' "Parenting Voices”. Solo Parent Identity and Co-Parent Identity in

Married Parents' Narratives of Meaningful Parenting Experiences'. Journal of Social and Personal

Relations I8(5): 69I-708. 
trinder, L., Beek, M. and connolly J. (2002) Making Contact: How Parents and Children Negotiate and Experience Contact after Divorce. London: Joseph Rowntree Foundation.

tronto, J.C. (1993) Moral Boundaries. A Political Argument for an Ethic of Care. London: Routledge.

Wallbank, J. (200I) Challenging Motherhood(s). London: Prentice Hall.

Warin, J., solomon, Y., Lewis, C. and Langford, W. (I999) Fathers, Work and Family Life. York: Joseph Rowntree Foundation.

WeEks, J., Donovan, C. and heaphy, B. (I999) 'Everyday Experiments: Narratives of Non-Heterosexual Relationships', in B. Silva and C. Smart (eds.) The New Family. London: Sage.

Welsh, E., buchanan, A., Flour, E. and lewis, J. (2004) 'Involved' Fathering and Child Well-being. York: Joseph Rowntree Foundation.

\section{CAMBRIDGE JOURNALS}

